\title{
Article \\ Impact of Genetic Risk Score and Dietary Protein Intake on Vitamin D Status in Young Adults from Brazil
}

\author{
Buthaina E. Alathari ${ }^{1,2}$, Nathália Teixeira Cruvinel ${ }^{3}$, Nara Rubia da Silva ${ }^{3}$, Mathurra Chandrabose ${ }^{4}$, \\ Julie A. Lovegrove ${ }^{1,5,6} \mathbb{D}_{\text {, Maria A. Horst }}{ }^{3, *(\mathbb{D})}$ and Karani S. Vimaleswaran 1,5,6,*(D)
}

Citation: Alathari, B.E.; Cruvinel, N.T.; da Silva, N.R.; Chandrabose, M.; Lovegrove, J.A.; Horst, M.A.; Vimaleswaran, K.S. Impact of Genetic Risk Score and Dietary Protein Intake on Vitamin D Status in Young Adults from Brazil. Nutrients 2022, 14, 1015. https://doi.org/10.3390/nu14051015

Academic Editor: Andrea Fabbri

Received: 27 January 2022

Accepted: 24 February 2022

Published: 28 February 2022

Publisher's Note: MDPI stays neutral with regard to jurisdictional claims in published maps and institutional affiliations.

Copyright: (C) 2022 by the authors. Licensee MDPI, Basel, Switzerland. This article is an open access article distributed under the terms and conditions of the Creative Commons Attribution (CC BY) license (https:// creativecommons.org/licenses/by/ $4.0 /)$.
1 Hugh Sinclair Unit of Human Nutrition, Department of Food and Nutritional Sciences, University of Reading, Harry Nursten Building, Pepper Lane, Reading RG6 6DZ, UK; b.e.a.a.alathari@pgr.reading.ac.uk (B.E.A.); j.a.lovegrove@reading.ac.uk (J.A.L.)

2 Department of Food Science and Nutrition, Faculty of Health Sciences, The Public Authority for Applied Education and Training, P.O. Box 14281, AlFaiha 72853, Kuwait

3 Nutritional Genomics Research Group, Faculty of Nutrition, Federal University of Goiás (UFG), Goiânia 74690-900, Brazil; nathaliateixeira@discente.ufg.br (N.T.C.); nutrinara@discente.ufg.br (N.R.d.S.)

4 Department of Psychology and Clinical Language Sciences, University of Reading, Harry Pitt Building, Earley Gate, Reading RG6 6ES, UK; m.e.chandrabose@student.reading.ac.uk

5 Institute for Food, Nutrition and Health, University of Reading, Reading RG6 6AH, UK

6 Institute of Cardiovascular and Metabolic Research, University of Reading, Reading RG6 6AA, UK

* Correspondence: aderuza@ufg.br (M.A.H.); v.karani@reading.ac.uk (K.S.V.); Tel.: +55-(62)-3209-6270 (M.A.H.); +44-(0)-118-378-8702 (K.S.V.)

\begin{abstract}
Given the relationship between vitamin D deficiency (VDD) and adverse outcomes of metabolic diseases, we investigated the interplay of dietary and genetic components on vitamin $\mathrm{D}$ levels and metabolic traits in young adults from Brazil. Genetic analysis, dietary intake, and anthropometric and biochemical measurements were performed in 187 healthy young adults (19-24 years). Genetic risk scores (GRS) from six genetic variants associated with vitamin D (vitamin D-GRS) and 10 genetic variants associated with metabolic disease (metabolic-GRS) were constructed. High vitamin D-GRS showed a significant association with low $25(\mathrm{OH}) \mathrm{D}$ concentrations $(p=0.001)$ and high metabolic-GRS showed a significant association with high fasting insulin concentrations $(p=0.045)$. A significant interaction was found between vitamin D-GRS and total protein intake (g/day) (adjusted for non-animal protein) on $25(\mathrm{OH}) \mathrm{D}$ ( $\left.p_{\text {interaction }}=0.006\right)$, where individuals consuming a high protein diet $(\geq 73 \mathrm{~g} / \mathrm{d})$ and carrying $>4$ risk alleles for VDD had significantly lower $25(\mathrm{OH}) \mathrm{D}(p=0.002)$ compared to individuals carrying $\leq 4$ risk alleles. Even though our study did not support a link between metabolic-GRS and vitamin D status, our study has demonstrated a novel interaction, where participants with high vitamin D-GRS and consuming $\geq 73 \mathrm{~g}$ of protein/day had significantly lower $25(\mathrm{OH}) \mathrm{D}$ levels. Further research is necessary to evaluate the role of animal protein consumption on VDD in Brazilians.
\end{abstract}

Keywords: 25(OH)D; genetic risk score; gene-diet interaction; nutrigenetics; protein intake; Brazil

\section{Introduction}

An increased prevalence of vitamin D deficiency (VDD) has been reported worldwide [1-3]; however, in South America, studies reporting the prevalence of vitamin D deficiency are scarce [4-6]. Brazil, the largest country in South America, has a low-latitude and elevated ultraviolet rays (UVB) [7] and mostly tropical weather conditions with high temperatures throughout the year [8]. Despite having abundant year-round sunshine, vitamin $\mathrm{D}$ deficiency and insufficiency have been reported by recent studies to be at $28.2 \%$ and $45.3 \%$, respectively, regardless of age or gender [5]. Dietary consumption of vitamin D is generally low in the Brazilian populace and the amount of vitamin D in foods in Brazil is not accurately known. Moreover, many food products do not list information about vitamin $\mathrm{D}$ quantity in the food composition table and this hinders any studies trying to 
assess the influence of dietary intake of vitamin D on serum 25(OH)D levels. In general, dietary sources of vitamin D are limited and the small bioavailable amounts found in foods are inadequate for the phycological requirements of the human body [5,9].

In Brazil, overweight and obesity are important health concerns. Overweight was reported at $43 \%$ in 2006, 53.8\% in 2016 [10] and has increased in prevalence to $57.5 \%$ in 2020 [11]. Obesity was reported at $11.8 \%$ in 2006, increased to $18.9 \%$ in 2016 [10] and increased in prevalence to $21.5 \%$ in 2020 in the Brazilian population [11]. The concern over the increased frequency of overweight and obesity is due to their poor health consequence and being a key risk factor to several chronic diseases such as diabetes, cardiovascular disorders and some types of cancer [12]. Type 2 diabetes (T2D) is another health issue of concern in the Brazilian population and the country is ranked 5th in the world for highest number of people with T2D [13]. Furthermore, a little over 75\% of T2D patients are either overweight or obese [14].

Several epidemiological studies demonstrated a relationship between low vitamin D status and metabolic traits [15-18]. Using genetic polymorphisms to explore the relationship between VDD and metabolic diseases can help minimize the inherent limitations of nutritional epidemiological studies $[19,20]$. The use of genotypic information limits the effect of residual confounding from unconsidered factors or uncollected data [21]. Given that there are limited nutrigenetic studies in the Brazilian young adult population, this study will examine the association of the vitamin D-related genetic risk score (GRS) and metabolic disease-related GRS with clinical, biochemical and anthropometric parameters [22,23], and examine interactions between the GRSs and lifestyle factors on metabolic disease outcomes in young Brazilian adults using a nutrigenetic approach.

\section{Methodology}

\subsection{Study Population}

Obesity, Lifestyle and Diabetes in Brazil (BOLD) is a cross-sectional study in young healthy Brazilian adults aged 19-24 years enrolled at the Federal University of Goiás (UFG) between the months of March and June 2019. The study took place as part of Gene-Nutrient Interactions ("GeNuIne" Collaboration) which is an ongoing collaboration aiming to examine the effect of genes and lifestyle on chronic diseases in ethnically diverse populations [24-27]. A baseline questionnaire was completed by all participants regarding health status, socioeconomic, and demographic status. Exclusion criteria included use of hypoglycemic or lipid-lowering drugs; use of vitamin or mineral supplements; undergoing any dietary intervention in the past 6 months; engaging in vigorous physical activity; having acute medical conditions such as fever, inflammation, infection, diarrhea, or being diagnosed with chronic diseases such as hypertension, diabetes mellitus, rheumatoid arthritis, cancer, or cardiovascular disease. In total, 200 individuals completed the BOLD study; however, for the present analysis after excluding 13 participants with incomplete genetic data the total number of participants included was 187. Ethical approval was granted by the Ethics Committee of the Federal University of Goiás (protocol number 3.007.456, 8 November 2018), and performed according to the ethical principles in the Declaration of Helsinki. All study participants signed an informed consent form.

\subsection{Anthropometric Measures}

Anthropometric measurements were taken by trained investigators using validated methods. Measurements of body weight, height and waist circumference (WC) were taken using identical techniques [28,29]. A Tanita ${ }^{\circledR}$ (Tanita Corporation, Itabashi, Tokyo, Japan) portable electronic scale was used to weigh participants, the maximum capacity was $150 \mathrm{~kg}$. Height measurements were taken using a stadiometer with a mobile rod. Measurements of WC were obtained by using a non-stretchable measuring tape. Calculation of body mass index (BMI) was performed using the following formula: weight $(\mathrm{kg}) /$ height $\left(\mathrm{m}^{2}\right)$. Dual Energy Radiological Absorptiometry scan (DXA) was used to measure body composition, using the Lunar DPX NT model (General Electric Medical Systems Lunar ${ }^{\circledR}$; Madison, WI, 
USA). Body fat percentage (BFP) was considered elevated when it was $30.0 \%$ for women and $20.0 \%$ for men [30-32].

\subsection{Biochemical Measures}

Blood samples were collected by a qualified professional, through a peripheral venous puncture in the morning after a $12 \mathrm{~h}$ fast (not eating or drinking anything but water), with additional advice not to consume alcohol $72 \mathrm{~h}$ before blood collection. Ethylene-diaminetetra acetic acid (EDTA) tubes using a BD Vacutainer ${ }^{\circledR}$ were used to collect blood samples and the samples were immediately processed after pooling at Romulo Rocha Laboratory (Goiânia, Brazil) to obtain plasma and serum, respectively. Serum vitamin D concentration was measured by chemiluminescence, using the model Architect i1000, Abbott Diagnostics [33]. The fasting blood glucose and insulin were analyzed by the enzymatic colorimetric technique, with an automatic System Vitros Chemistry 950 XRL (Johnson \& Johnson, New Brunswick, NJ, USA). Glycated hemoglobin (HbA1c) measurements were undertaken using high-pressure liquid chromatography (HPLC-Bio-Rad Laboratories, Hercules, CA, USA).

\subsection{Assessment of Sun Exposure and Dietary Intake}

Our study was conducted in the state of Goiás, which is in the central-west region of Brazil, during the fall season between the months of March and June 2019 where the average annual temperature is $24.6{ }^{\circ} \mathrm{C}$ [34] and the sunlight hours range between 11 and $12 \mathrm{~h}$ [35]. Sun exposure was assessed using a specific validated questionnaire adapted from the MIT-UV study protocol, which includes the usual time of daily exposure, commonly exposed body parts, use of sunscreen and factor (SPF) and skin type [36]. Daily sun exposure was recorded for 7 days and determined in 3 categories and assigned a numerical value: 1 = under 5 min of sun exposure; 2 = between 5 and 30 min of sun exposure; 3 = over $30 \mathrm{~min}$ of sun exposure. Total sun exposure for the week was determined by summing up the numerical values for each day which resulted in a range of 7-21 representing sun exposure for each participant. A median value of 16 was used to define participants, where individuals with value $<16$ and $\geq 16$ were categorized as those with low and high sun exposures, respectively [36].

Intakes of food were assessed by experienced nutritionists using a three-day food diary (two weekdays and one weekend day) [37]. Food measuring equipment such as measuring spoons and measuring cups were provided to participants to aid them in approximating portion sizes of foods. To determine exact amounts of consumed foods the software Avanutri Online ${ }^{\circledR}$ diet calculation (Avanutri Informática Ltd., Rio de Janeiro, Brazil) was used to convert food intakes into grams. The protein consumption was categorized as animal (including all kind of meat, fish, eggs, milk, and dairy products), and non-animal protein source in grams.

\subsection{SNP Selection and Genotyping}

We selected a total of 16 SNPs, of which 6 SNPs previously showed associations with vitamin D levels and 10 SNPs previously showed associations with metabolic traits in several ethnic groups. Six vitamin D-related SNPs were included in the analysis: vitamin D receptor (VDR) SNPs rs2228570 and rs7975232 [38,39]; 7-dehydrocholesterol reductase (DHCR7) SNP rs12785878 [40-43]; 25-hydroxylase (CYP2R1) SNP rs12794714 [43,44]; 24-hydroxylase (CYP24A1) SNP rs6013897 [41,45]; and vitamin D binding protein (DBP)/group-specific component (GC) SNP rs2282679 [40,44]. Ten metabolic disease-related SNPs were included in the analysis: Fat mass and obesity-associated (FTO) SNPs rs8050136 and rs9939609 [20,46-51]; transcription factor 7-like 2 (TCF7L2) SNPs rs12255372 and rs7903146 [20,52-58]; melanocortin 4 receptor $(M C 4 R)$ SNP rs17782313 [20,59-62]; potassium voltage-gated channel subfamily Q member 1 (KCNQ1) SNPs rs2237895 and rs2237892 [63,64]; cyclin dependent kinase inhibitor 2A/B (CDKN2A/B) SNPs rs10811661 [53,65-67]; Peroxisome Proliferator Activated Receptor Gamma (PPARG) SNP rs1801282 [53,68-70]; calpain 10 (CAPN10) SNP rs5030952 [71,72]. 
DNA analysis was performed by collecting blood samples ( $3 \mathrm{~mL}$ each) in EDTA tubes BD Vacutainer ${ }^{\circledR}$ tubes which were transferred in a $\left(-80^{\circ} \mathrm{C}\right)$ temperature-controlled environment by the World Courier Company to perform genotyping at the LGC Genomics, London, UK (http: / / www.lgcgroup.com/services/genotyping, accessed on 26 February 2022).

\subsection{Statistical Analysis}

Statistical software SPSS (v27; SPSS Inc., Chicago, IL, USA) was used to conduct statistical analyses. The selected 16 SNPs were in Hardy-Weinberg equilibrium (HWE) $(p>0.05)$, which was tested using a goodness-of-fit chi square test (Supplementary Table S1). Descriptive features of study population were given as means and standard deviations (SD) for continuous variables and comparisons between groups were tested using independent samples t-test. Shapiro-Wilk test of normality was conducted on all continuous variables to verify the normality of the data in the variables. Log-transformation was performed on all non-normally distributed variables, and these variables included age (years), $\mathrm{BMI}\left(\mathrm{kg} / \mathrm{m}^{2}\right)$, waist circumference (WC) (cm), glucose (mg/dL), insulin (nmlU/L), HbA1c (ng/mL), total energy intake (Kcal), total carbohydrate $(\mathrm{g})$, total protein, animal protein, non-animal protein $(\mathrm{g})$, total fat $(\mathrm{g})$, fiber $(\mathrm{g})$, and $25(\mathrm{OH}) \mathrm{D}$ level $(\mathrm{ng} / \mathrm{mL})$.

Vitamin D cut-offs were decided based on the 2020 revised reference values of 'The Brazilian Society of Endocrinology and Metabolism and The Brazilian Society of Clinical Pathology/Laboratory Medicine'. The vitamin D values for the general Brazilian population were defined as normal when $25(\mathrm{OH}) \mathrm{D}$ levels were between 20 and $60 \mathrm{ng} / \mathrm{mL}$, and deficient when 25(OH)D levels were below $20 \mathrm{ng} / \mathrm{mL}$ [73].

Two independent genetic risk scores (GRSs) were created by the addition of the sums of the risk allele across each SNP. The vitamin D-GRS was computed from six SNPs and the metabolic disease GRS was computed from 10 SNPs. Each SNP had a value of 0, 1, or 2 and this value indicates the number of risk alleles for each GRS. Subsequently, these values were calculated by adding the number of risk alleles across each SNP. For each individual GRS, risk allele scores were then divided by the median and categorized into a "low genetic risk group" and a "high genetic risk group." Using the median of vitamin D-related GRS, low risk and high risk were categorized as individuals carrying $\leq 4(n=112)$ and those carrying $>4(n=71)$ risk alleles, respectively. For the metabolic disease- GRS, low risk relates to individuals carrying $\leq 5(n=123)$ and high risk relates to those carrying $>5$ $(n=60)$ risk alleles. Figure 1 denotes the study design of the performed analyses.

Linear regression models were used to analyze the association of vitamin D-related GRS and the metabolic disease-related GRS on anthropometric and biochemical outcomes (BMI, WC, 25(OH)D, glucose, HbA1c, fasting insulin), respectively. Additionally, the interaction between GRSs and dietary factors on clinical and biochemical variables were tested using linear regression models by including the interaction term (GRS*dietary factor). Regression models were adjusted for age, BMI, sun exposure and total energy intake, wherever appropriate. Dietary factors included total carbohydrate, total protein (animal protein, non-animal protein), total fat, and fiber intake in grams. Furthermore, in cases where interactions were statistically significant, study participants were split by the tertiles of dietary consumption and further analyzed. 


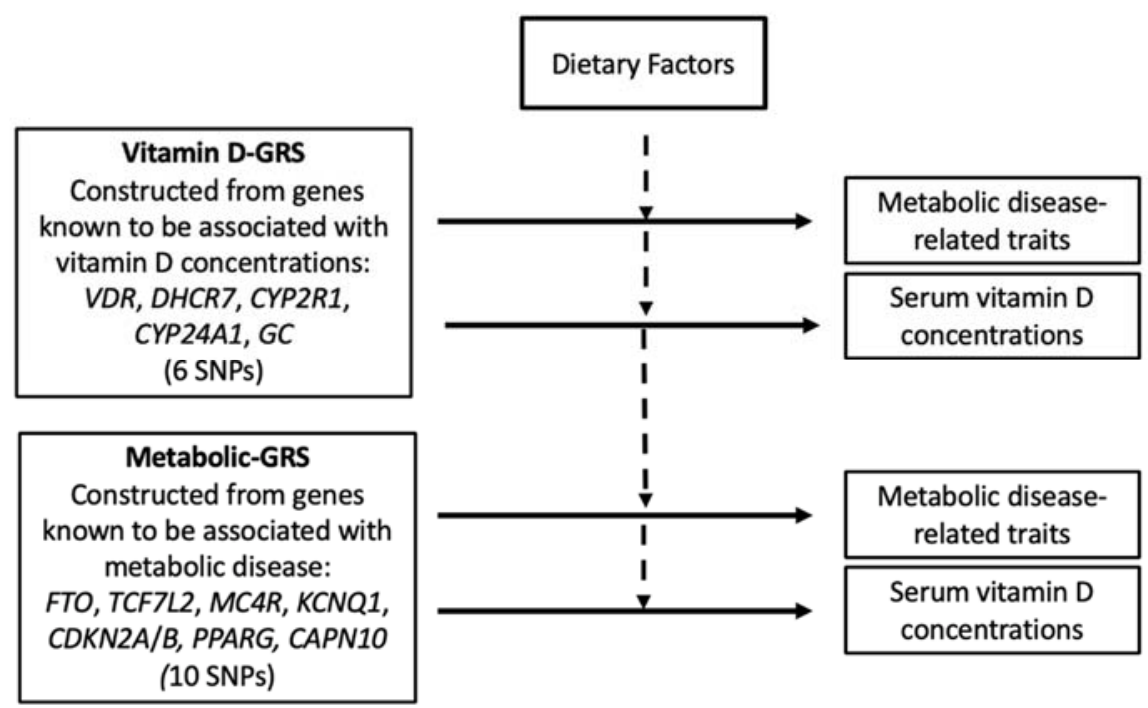

Figure 1. Study design. The one-sided horizontal arrows with solid lines represent the genetic associations and the one-sided vertical arrows with dotted lines represent the interactions between GRS and diet on clinical and biochemical measurements. The association of vitamin D-GRS with $25(\mathrm{OH}) \mathrm{D}$ levels and metabolic traits and the association of the metabolic-GRS with $25(\mathrm{OH}) \mathrm{D}$ levels and metabolic traits and were tested. Furthermore, analyses of the effect of dietary factors on these genetic associations were performed. Abbreviations: GRS: genetic risk score; SNP: single nucleotide polymorphism; VDR: Vitamin D Receptor; DHCR7: 7-dehydrocholesterol reductase; CYP2R1: 25-hydroxylase; CYP24A1: 24-hydroxylase; GC: group-specific component; FTO: fat mass and obesity-associated gene; TCF7L2: transcription factor 7-like 2 gene; $M C 4 R$ : melanocortin 4 receptor gene; KCNQ1: potassium voltage-gated channel subfamily Q member 1; CDKN2A/B: cyclin dependent kinase inhibitor 2A/B; PPARG: Peroxisome Proliferator Activated Receptor Gamma; CAPN10: calpain 10.

\section{Results}

\subsection{Characteristics of Participants}

Anthropometric, biochemical, and dietary parameters of the BOLD study participants were compared based on $25(\mathrm{OH}) \mathrm{D}$ status and are summarized in Table 1 . No significant differences were found between participants with normal 25(OH)D levels and participants with $25(\mathrm{OH}) \mathrm{D}$ deficiency except for total protein intake $(\mathrm{g})(p=0.008)$.

Table 1. Baseline features of study partakers stratified by $25(\mathrm{OH}) \mathrm{D}$ status.

\begin{tabular}{|c|c|c|c|c|c|}
\hline $\begin{array}{c}\text { Characteristics of Study } \\
\text { Participants }\end{array}$ & $n$ & $\begin{array}{l}\text { Normal Vitamin D Status } \\
25(\mathrm{OH}) \mathrm{D} \geq 20 \mathrm{ng} / \mathrm{mL}\end{array}$ & $n$ & $\begin{array}{c}\text { Deficient Vitamin D Status } \\
25(\mathrm{OH}) \mathrm{D}<20 \mathrm{ng} / \mathrm{mL}\end{array}$ & $p$ Value \\
\hline Age (years) & 154 & $21.32 \pm 1.71$ & 31 & $21.35 \pm 1.56$ & 0.928 \\
\hline $\operatorname{BMI}\left(\mathrm{kg} / \mathrm{m}^{2}\right)$ & 154 & $23.01 \pm 3.87$ & 31 & $23.76 \pm 5.66$ & 0.370 \\
\hline $\mathrm{WC}(\mathrm{cm})$ & 154 & $74.05 \pm 11.89$ & 31 & $76.60 \pm 14.04$ & 0.291 \\
\hline $\mathrm{BFP}(\%)$ & 154 & $33.76 \pm 10.65$ & 31 & $34.57 \pm 11.05$ & 0.702 \\
\hline Glucose (mg/dl) & 156 & $86.74 \pm 6.79$ & 31 & $88.35 \pm 7.29$ & 0.235 \\
\hline $\mathrm{HbA} 1 \mathrm{c}(\%)$ & 156 & $4.73 \pm 0.26$ & 31 & $4.72 \pm 0.22$ & 0.911 \\
\hline Fasting Insulin (uIU/mL) & 156 & $8.72 \pm 3.69$ & 31 & $8.80 \pm 4.09$ & 0.911 \\
\hline Total Energy Intake (kcal) & 156 & $1793 \pm 591$ & 31 & $2024.12 \pm 676.96$ & 0.054 \\
\hline Total Protein $(\mathrm{g})$ & 156 & $75.20 \pm 28.17$ & 31 & $90.43 \pm 33.48$ & 0.008 \\
\hline Total Carbohydrate (g) & 156 & $230.67 \pm 84.32$ & 31 & $258.08 \pm 99.59$ & 0.111 \\
\hline Total Fat (g) & 156 & $63.34 \pm 23.43$ & 31 & $70.017 \pm 24.88$ & 0.153 \\
\hline Dietary Fiber (g) & 156 & $14.45 \pm 8.48$ & 31 & $16.39 \pm 9.68$ & 0.258 \\
\hline
\end{tabular}

Data is presented as means $\pm \mathrm{SD}, p$ values were calculated by using the independent $\mathrm{t}$ test. Vitamin $\mathrm{D}$ cut-off points were created on the recommendations of the Brazilian Society of Endocrinology and Metabolism and the Brazilian Society of Clinical Pathology/Laboratory Medicine vitamin D levels [73]. Abbreviations: BMI: body mass index; WC: waist circumference; BFP: body fat percentage; HbA1c: glycated hemoglobin. 


\subsection{Association between Vitamin D-GRS and Anthropometric and Biochemical Measurements}

There was a statistically significant association between vitamin D-GRS and serum $25(\mathrm{OH}) \mathrm{D}$ concentrations $(p=0.001)$. Individuals who carried $>4$ vitamin $\mathrm{D}$ risk alleles (mean \pm SE: $1.38 \pm 0.02$ ) had significantly lower $25(\mathrm{OH}) \mathrm{D}$ levels compared to participants carrying $\leq 4$ risk alleles (mean $\pm \mathrm{SE}: 1.45 \pm 0.01$ ) (Figure $2 \mathrm{~A}$ ).

(A)

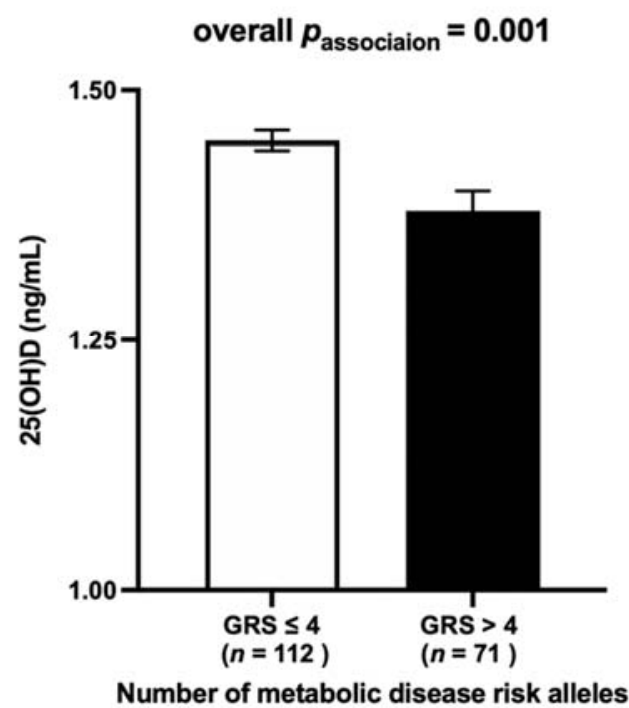

(B)

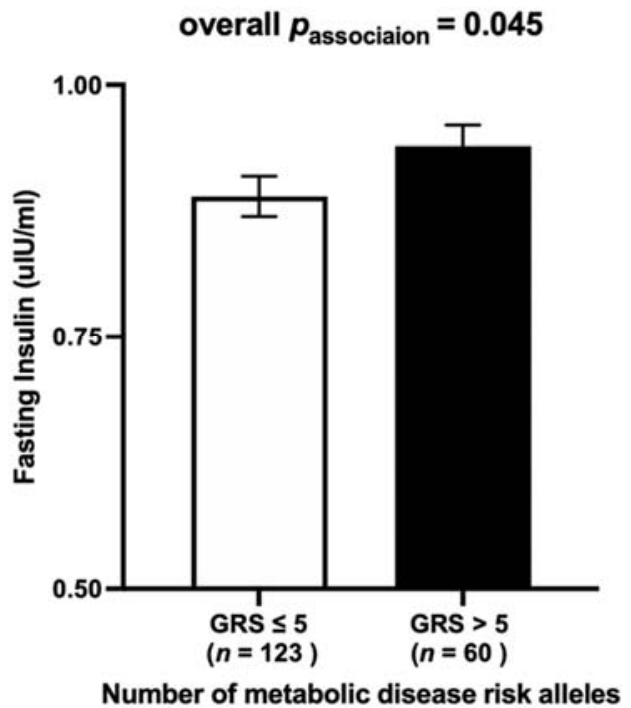

Figure 2. (A) The association between vitamin D-GRS and $\log 25(\mathrm{OH}) \mathrm{D}$. Participants carrying $>4$ vitamin D risk alleles (mean \pm SE: $1.38 \pm 0.02$ ) had lower $25(\mathrm{OH}) \mathrm{D}$ levels compared to participants with $\leq 4$ risk alleles (mean \pm SE: $1.45 \pm 0.01$ ). (B) The association between metabolic-GRS and log fasting insulin. Participants carrying $>5$ metabolic risk alleles (mean \pm SE: $0.94 \pm 0.02$ ) had higher fasting insulin levels compared to participants with $\leq 5$ risk alleles (mean \pm SE: $0.89 \pm 0.02$ ).

\subsection{Association between Metabolic-GRS and Anthropometric and Biochemical Measurements}

A statistically significant association was observed between metabolic-GRS and fasting insulin $(p=0.045)$, where individuals who carried $>5$ metabolic risk alleles (mean \pm SE: $0.94 \pm 0.02$ ) had significantly higher fasting insulin levels compared to individuals with $\leq 5$ risk alleles (mean $\pm \mathrm{SE}: 0.89 \pm 0.02$ ) (Figure $2 \mathrm{~B}$ ).

\subsection{Interaction between the Vitamin D-GRS and Dietary Factors on Biochemical and Anthropometric Measurements}

A statistically significant interaction was found between the vitamin D-GRS and total protein intake $(\mathrm{g})$ on $\log 25(\mathrm{OH}) \mathrm{D}$ concentrations $\left(p_{\text {interaction }}=0.006\right)$, where participants who had high protein intake $(\geq 73 \mathrm{~g} / \mathrm{d})$ and $>4$ risk alleles, had significantly lower log $25(\mathrm{OH}) \mathrm{D}$ concentrations (mean $\pm \mathrm{SE} 1.36 \pm 0.021, p=0.001)$ than participants with $\leq 4$ risk alleles (mean \pm SE: $1.46 \pm 0.019, p=0.001$ ). Even after adjusting for non-animal protein sources, the interaction of vitamin D-GRS with protein intake (g) was statistically significant, where a participants with $>4$ risk alleles had significantly lower $\log 25(\mathrm{OH}) \mathrm{D}$ concentrations (mean \pm SE $1.36 \pm 0.021, p=0.002$ ) than participants with $\leq 4$ risk alleles (mean \pm SE: $1.46 \pm 0.019, p=0.002$ ), (Figure 3 ). In addition, there was also a significant interaction of vitamin D-GRS with total protein intake $(\mathrm{g})$ on BFP $\left(p_{\text {interaction }}=0.049\right)$, and with fat intake $(\mathrm{g})$ on fasting glucose $\left(p_{\text {interaction }}=0.019\right)$, and with MUFA intake $(\mathrm{g})$ on fasting glucose concentrations $\left(p_{\text {interaction }}=0.027\right)$. 


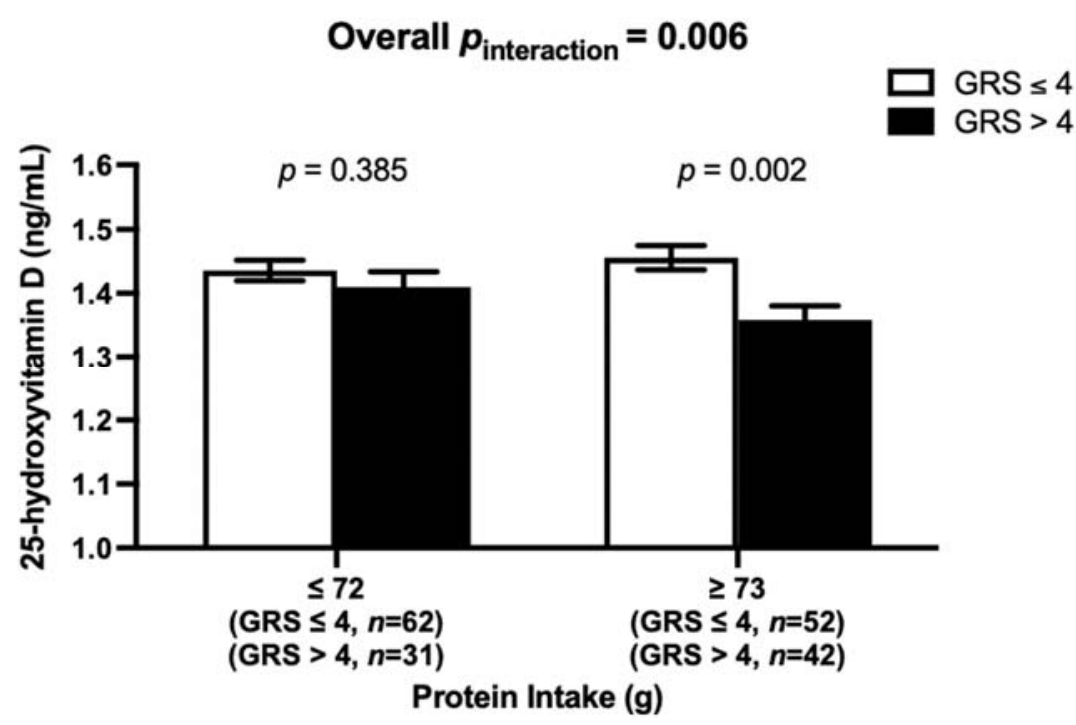

Figure 3. Interaction between vitamin D-GRS and total dietary protein intake (g) on $\log 25(\mathrm{OH}) \mathrm{D}$ $\left(p_{\text {interaction }}=0.006\right)$ adjusted for non-animal protein intake. Participants who had high protein intake $(\geq 73 \mathrm{~g} /$ day) and GRS $>4$ (mean \pm SE $1.36 \pm 0.021)$ had significantly lower $25(\mathrm{OH}) \mathrm{D}(p=0.002)$ than participants with GRS $\leq 4$ (mean \pm SE: $1.46 \pm 0.019$ ).

\subsection{Interaction between the Metabolic-GRS and Dietary Factors on Clinical and Biochemical Measurements}

There was no significant interaction between metabolic-GRS and dietary intake on serum 25(OH)D concentrations and clinical and biochemical factors $(p>0.079$ for all comparisons), respectively (Supplementary Table S2).

\section{Discussion}

As far as we know, this study is the first to examine the link between vitamin D status and metabolic disease-related traits using a nutrigenetic approach in young healthy Brazilian adults. Our study demonstrated the association of the high vitamin D-GRS with lower serum vitamin D concentrations and the association of metabolic-GRS with fasting insulin concentration. The main finding of this study is a significant interaction between the vitamin D-GRS and total protein intake on serum vitamin D levels after adjusting for non-animal protein intake. The association of total protein intake in participants with higher genetic risk of VDD on $25(\mathrm{OH}) \mathrm{D}$ levels is interesting; further investigation of the impact of higher protein intakes (from animal and non-animal sources) on vitamin D status using a randomized controlled trial would be helpful to illustrate whether this is a true finding.

In our study, we generated a GRS based on six vitamin D-related SNPs in genes involved in vitamin D metabolism. The vitamin D-GRS was associated with low vitamin $\mathrm{D}$ levels indicating that it is an ideal instrument for vitamin D deficiency. Even though we were unable to provide statistical evidence for the association between genetically instrumented vitamin D-GRS and metabolic disease traits in our study, we identified that individuals who had higher genetic risk alleles (GRS > 4) and consumed higher amounts of protein ( $\geq 73 \mathrm{~g} /$ day) had significantly lower $25(\mathrm{OH}) \mathrm{D}$ than participants with lesser risk alleles (GRS $\leq 4$ ). Studies looking into the effect of dietary intake in people with high genetic risk for vitamin D deficiency are uncommon and studies reporting on the effect of dietary protein intake on vitamin $\mathrm{D}$ status for individuals with high genetic risk of vitamin $\mathrm{D}$ deficiency are non-existent. We previously investigated the effect of genetic factors and dietary intake in the Indonesian Minangkabau women and discovered a significant interaction between dietary carbohydrate intake and high vitamin $\mathrm{D}$ genetic risk on body fat composition $(p$-interaction $=0.049)$ [19]. This implicates the significance of genetic and dietary heterogeneity that exists across multiple ethnic groups. A randomized 
weight-loss intervention trial [74] in 118 overweight and obese participants in the United States, where the participates were randomly assigned to a weight-loss diet for two years with different percentages of caloric energy from macronutrients, showed a significant interaction between vitamin D GRS and dietary fat intake on two-year changes in wholebody bone mineral density ( $p$-interaction $=0.02)$. Nevertheless, this study did not examine vitamin D status [75]. In comparison to the previous studies, our findings are novel and hence further studies relating to vitamin D GRS-diet interactions on vitamin D status are necessary to corroborate our findings.

The mechanism of the possible effect of high protein intake on vitamin D concentrations particularly in genetically VDD susceptible individuals is not clear, however, it could be specifically driven by animal protein sources as the findings in our study remained significant after adjustments for non-animal protein sources. Our finding is contrary to the results from a couple of studies on bone and skeletal health where it was reported that high protein intake positively interacts with vitamin D metabolism through the production of insulin-like growth factor-I (IGF-I) and enhances renal production of 1,25 dihydroxyvitamin D [76,77]. Nevertheless, these studies did not specify the sources of the dietary protein that enhanced vitamin D metabolism. In a cross-sectional study investigating vitamin $\mathrm{D}$ concentrations in 176 healthy vegetarian vs. non-vegetarian Pakistani individuals, a significantly lower serum $25(\mathrm{OH}) \mathrm{D}(p=0.001)$ was found in individuals who were nonvegetarians $(n=9$; mean \pm SD: $9.39 \pm 2.45)$ compared to vegetarians $(n=83$; mean $\pm S D$ : $13.78 \pm 3.48)[78]$, but whether the reduced $25(\mathrm{OH}) \mathrm{D}$ levels were influenced by increased animal protein intake was not investigated. The effect of dietary animal protein intake on vitamin $\mathrm{D}$ concentrations requires future investigations to confirm or refute our findings and to determine the molecular mechanisms of action.

According to the 2008-2009 data from the Brazilian Household Expenditure Surveys (HES), dietary protein and fat intakes have increased in Brazil while carbohydrates content has decreased [79]. Increase in protein intake was due to increased consumption of animal flesh and animal products. The mean daily caloric intake from a nationwide cross-sectional survey using the HES data of 2008-2009 was estimated to be $1902 \mathrm{kcal}$. The total carbohydrate intake contributed to $56 \%$ of the total energy, total fat intake contributed to $27 \%$ of total energy and total protein intake contributed to $17 \%$ of total energy with animal protein providing $10 \%$ of the total energy intake [79]. According to internationally accepted dietary guidelines [80-82] the total daily recommended protein intake is between 10 and $15 \%$ of total daily energy intake; this translates into $48-71 \mathrm{~g}$ of daily protein intake from the estimated caloric intake of the Brazilian population (1902 kcal). In our study, the protein intake of our participants ranged between 73 and $217 \mathrm{~g} /$ day which is higher than the daily protein intake recommendations. Hence, adherence to the dietary protein intake recommendations may be an effective strategy to overcome the genetic risk of vitamin $\mathrm{D}$ deficiency in Brazilians.

The main strengths of the study are that it is the first nutrigenetics analysis to investigate interactions between vitamin D-GRS and metabolic related traits in a healthy young Brazilian population. A genetic approach is favorable to observational studies as the genotype is not modified by the disease and is free from confounding [21,83]. Additionally, the use of a GRS analysis instead of a single SNP analysis is a favorable approach as the GRS method has a greater statistical power in predicting genetic predisposition over the single-locus approach [22,84]. Furthermore, biochemical and anthropometric measures were determined using validated techniques by skilled staff which improved the precision of these estimates. However, some limitations need to be acknowledged. One of the main limitations of the study is the small sample size, nevertheless, significant gene-diet interactions were identified suggesting that the study is well powered. Another limitation is that dietary intake was assessed using three-day self-reported food records; despite being a validated and widely used method, we cannot discount the effect of reporting and recall bias. Furthermore, the Brazilian population is an admixture of many genetic ancestries from all over the world which makes it genetically heterogenous and could cause biased 
estimates of disease risk because of population stratification [85-88]. Finally, the study population included healthy young adults which may not be demonstrative of the total Brazilian population.

\section{Conclusions}

In conclusion, this study discovered a novel interaction between vitamin D-GRS and total protein intake on serum $25(\mathrm{OH}) \mathrm{D}$ levels after adjusting for non-animal protein intake in a young Brazilian adult population, where individuals with high GRS consuming more than $73 \mathrm{~g}$ of protein/day had significantly lower $25(\mathrm{OH}) \mathrm{D}$ levels. The finding is of particular interest for setting public health recommendations for preventing $25(\mathrm{OH}) \mathrm{D}$ deficiency in genetically susceptible young healthy Brazilian individuals given the increase in the dietary intake of animal protein in recent years [79]. Further investigations and randomized controlled trials are required to shed more light on the effect of increased animal protein intake on vitamin D levels, especially in individuals genetically susceptible to VDD to enable effective public health interventions to prevent VDD.

Supplementary Materials: The following supporting information can be downloaded at: https: //www.mdpi.com/article/10.3390/nu14051015/s1, Table S1: Genotypic distribution and allelic frequencies of the single nucleotide polymorphisms that were used to create the genetic risk score [89]. Table S2: Interactions between vitamin D-GRS and dietary factors on clinical and biochemical measurements.

Author Contributions: K.S.V. conceived, supervised, and designed the nutrigenetic study; B.E.A. and M.C. performed the statistical analyses, interpreted the data and drafted the original manuscript; B.E.A. and K.S.V. edited and reviewed the draft; N.T.C. and N.R.d.S. carried out data collection, monitoring and evaluation of participants, and project administration; K.S.V., M.A.H. and J.A.L. critically reviewed the manuscript; K.S.V. and M.A.H. carried out project design and administration, funding acquisition and data curation. All authors have read and agreed to the published version of the manuscript.

Funding: The study was funded by the Conselho Nacional das Fundações Estaduais de Amparo à Pesquisa (CONFAP)-UK Academies Researcher Mobility award.

Institutional Review Board Statement: The BOLD study was conducted according to the guidelines of the Declaration of Helsinki and was approved by the Ethical Review Committee of the Federal University of Goiás (protocol number 3.007.456, 08/11/2018). All participants gave their written informed consent before participating.

Informed Consent Statement: The consent for publication has been obtained from all the participants.

Data Availability Statement: The datasets used and/or analyzed during the current study are available from the corresponding author on reasonable request.

Acknowledgments: We acknowledge and thank all the BOLD study participants for their cooperation. Karani S Vimaleswaran acknowledges the Public Authority for Applied Education and Training of Kuwait for the scholarship given to Buthaina AlAthari. Maria A Horst acknowledges the Master scholarships from the Brazilian agency 'Coordenação de Aperfeiçoamento de Pessoal de Nível Superior' (CAPES) given to Nathalia T Cruvinel and Nara R da Silva.

Conflicts of Interest: The authors declare no conflict of interest.

\section{Abbreviations}

VDD: vitamin D deficiency; T2D: type 2 diabetes; WC: waist circumference; BMI: body mass index; HbA1c: glycated hemoglobin; VDR: vitamin D receptor; DHCR7: 7-dehydrocholesterol reductase; CYP2R1: 25-hydroxylase; CYP24A1: 24-hydroxylase; DBP: vitamin D binding protein; GC: group-specific component; $C A S R$ : calcium sensing receptor; FTO: fat mass and obesity-associated gene; TCF7L2: transcription factor 7-like 2 gene; MC4R: melanocortin 4 receptor gene; KCNQ1: potassium voltage-gated channel subfamily $Q$ member $1 ; C D K N 2 A / B$ : cyclin dependent kinase inhibitor 2A/B; PPARG: peroxisome proliferator activated receptor gamma; CAPN10: calpain 10; GRS: 
genetic risk score; SNP: single nucleotide polymorphism; HWE: Hardy-Weinberg equilibrium; SD: standard deviation; BOLD: Obesity, Lifestyle and Diabetes; HES: Household Expenditure Surveys.

\section{References}

1. Amrein, K.; Scherkl, M.; Hoffmann, M.; Neuwersch-Sommeregger, S.; Köstenberger, M.; Tmava Berisha, A.; Martucci, G.; Pilz, S.; Malle, O. Vitamin D deficiency 2.0: An update on the current status worldwide. Eur. J. Clin. Nutr. 2020, 74, 1498-1513. [CrossRef] [PubMed]

2. Bouillon, R.; Marcocci, C.; Carmeliet, G.; Bikle, D.; White, J.H.; Dawson-Hughes, B.; Lips, P.; Munns, C.F.; Lazaretti-Castro, M.; Giustina, A.; et al. Skeletal and extraskeletal actions of vitamin d: Current evidence and outstanding questions. Endocr. Rev. 2019, 40, 1109-1151. [CrossRef]

3. Benhamou, J.; Schindler, C.; Rutishauser, J. Prevalence of vitamin D deficiency in an inpatient population in the Swiss Canton of Basel-country. Swiss. Med. Wkly. 2021, 151, w20470. [CrossRef]

4. Brito, A.; Cori, H.; Olivares, M.; Fernanda Mujica, M.; Cediel, G.; López de Romaña, D. Less than adequate vitamin D status and intake in Latin America and the Caribbean:a problem of unknown magnitude. Food Nutr. Bull. 2013, 34, 52-64. [CrossRef]

5. Pereira-Santos, M.; Santos, J.; Carvalho, G.Q.; Santos, D.B.D.; Oliveira, A.M. Epidemiology of vitamin D insufficiency and deficiency in a population in a sunny country: Geospatial meta-analysis in Brazil. Crit. Rev. Food. Sci. Nutr. 2019, 59, 2102-2109. [CrossRef]

6. Bandeira, F.; Griz, L.; Dreyer, P.; Eufrazino, C.; Bandeira, C.; Freese, E. Vitamin D deficiency: A global perspective. Arq Bras Endocrinol. Metabol. 2006, 50, 640-646. [CrossRef]

7. Eloi, M.; Horvath, D.V.; Szejnfeld, V.L.; Ortega, J.C.; Rocha, D.A.; Szejnfeld, J.; Castro, C.H. Vitamin D deficiency and seasonal variation over the years in São Paulo, Brazil. Osteoporos. Int. 2016, 27, 3449-3456. [CrossRef]

8. De Arêa Leão Borges Vera, C.; Callejas Ivan Julio, A.; Durante, L.C. Thermal sensation in outdoor urban spaces: A study in a Tropical Savannah climate, Brazil. Int. J. Biometeorol. 2020, 64, 533-545. [CrossRef]

9. Peters, B.S.E.; Dos Santos, L.C.; Fisberg, M.; Wood, R.J.; Martini, L.A. Prevalence of vitamin D insufficiency in Brazilian adolescents. Ann. Nutr. Metab. 2009, 54, 15-21. [CrossRef]

10. Triaca, L.M.; dos Santos, A.M.A.; Tejada, C.A.O. Socioeconomic inequalities in obesity in Brazil. Econ. Hum. Biol. 2020, 39 , 100906. [CrossRef] [PubMed]

11. Brasil, Vigitel Brasil 2020—Vigilância de Fatores de Risco e Proteção Para Doenças Crônicas por Inquérito Telefônico. Brasília: Ministério da Saúde. 2021. Available online: https:/ /www.gov.br/saude/pt-br/centrais-de-conteudo/publicacoes/publicacoessvs/vigitel/relatorio-vigitel-2020-original.pdf/view (accessed on 15 November 2021).

12. Dos Passos, C.M.; Maia, E.G.; Levy, R.B.; Martins, A.P.B.; Claro, R.M. Association between the price of ultra-processed foods and obesity in Brazil. Nutr. Metab. Cardiovasc. Dis. 2020, 30, 589-598. [CrossRef]

13. Correr, C.J.; Coura-Vital, W.; Frade, J.C.Q.P.; Nascimento, R.C.R.M.; Nascimento, L.G.; Pinheiro, E.B.; Ferreira, W.M.; Reis, J.S.; Melo, K.F.S.; Pontarolo, R.; et al. Prevalence of people at risk of developing type 2 diabetes mellitus and the involvement of community pharmacies in a national screening campaign: A pioneer action in Brazil. Diabetol. Metab. Syndr. 2020, 12, 89. [CrossRef] [PubMed]

14. Coutinho, W.F.; Silva Júnior, W.S. Diabetes care in Brazil. Ann. Glob. Health 2015, 81, 735-741. [CrossRef] [PubMed]

15. Mezza, T.; Muscogiuri, G.; Sorice, G.P.; Prioletta, A.; Salomone, E.; Pontecorvi, A.; Giaccari, A. Vitamin D Deficiency: A new risk factor for type 2 diabetes. Ann. Nutr. Metab. 2012, 61, 337-348. [CrossRef]

16. Savastano, S.; Barrea, L.; Savanelli, M.C.; Nappi, F.; Di Somma, C.; Orio, F.; Colao, A. Low vitamin D status and obesity: Role of nutritionist. Rev. Endocr. Metab. Disord. 2017, 18, 215-225. [CrossRef]

17. Scragg, R. Vitamin D and type 2 diabetes. Are We Ready Prev. Trial? 2008, 57, 2565-2566. [CrossRef]

18. Vranić, L.; Mikolašević, I.; Milić, S. Vitamin D deficiency: Consequence or cause of obesity? Medicina 2019, 55, 541. [CrossRef]

19. Alathari, B.E.; Aji, A.S.; Ariyasra, U.; Sari, S.R.; Tasrif, N.; Yani, F.F.; Sudji, I.R.; Lovegrove, J.A.; Lipoeto, N.I.; Vimaleswaran, K.S. Interaction between vitamin D-related genetic risk score and carbohydrate intake on body fat composition: A study in southeast asian minangkabau women. Nutrients 2021, 13, 326. [CrossRef] [PubMed]

20. Alathari, B.E.; Bodhini, D.; Jayashri, R.; Lakshmipriya, N.; Shanthi Rani, C.S.; Sudha, V.; Lovegrove, J.A.; Anjana, R.M.; Mohan, V.; Radha, V.; et al. A Nutrigenetic approach to investigate the relationship between metabolic traits and vitamin $\mathrm{d}$ status in an Asian Indian population. Nutrients 2020, 12, 1357. [CrossRef]

21. Fenech, M.; El-Sohemy, A.; Cahill, L.; Ferguson, L.R.; French, T.-A.C.; Tai, E.S.; Milner, J.; Koh, W.-P.; Xie, L.; Zucker, M.; et al. Nutrigenetics and nutrigenomics: Viewpoints on the current status and applications in nutrition research and practice. J. Nutr. Nutr. 2011, 4, 69-89. [CrossRef]

22. Hüls, A.; Krämer, U.; Carlsten, C.; Schikowski, T.; Ickstadt, K.; Schwender, H. Comparison of weighting approaches for genetic risk scores in gene-environment interaction studies. BMC Genet. 2017, 18, 115. [CrossRef] [PubMed]

23. Udler, M.S.; McCarthy, M.I.; Florez, J.C.; Mahajan, A. Genetic risk scores for diabetes diagnosis and precision medicine. Endocr. Rev. 2019, 40, 1500-1520. [CrossRef] [PubMed]

24. Vimaleswaran, K.S. Gene-nutrient interactions on metabolic diseases: Findings from the GeNuIne collaboration. Nutr. Bull. 2017, 42, 80-86. [CrossRef] 
25. Vimaleswaran, K.S. A nutrigenetics approach to study the impact of genetic and lifestyle factors on cardiometabolic traits in various ethnic groups: Findings from the GeNuIne Collaboration. Proc. Nutr. Soc. 2020, 79, 194-204. [CrossRef] [PubMed]

26. Vimaleswaran, K.S. GeNuIne (gene-nutrient interactions) Collaboration: Towards implementing multi-ethnic population-based nutrigenetic studies of vitamin B12 and D deficiencies and metabolic diseases. Proc. Nutr. Soc. 2021, 80, 435-445. [CrossRef] [PubMed]

27. Isgin-Atici, K.; Alathari, B.E.; Turan-Demirci, B.; Sendur, S.N.; Lay, I.; Ellahi, B.; Alikasifoglu, M.; Erbas, T.; Buyuktuncer, Z.; Santhanakrishnan, V.K. Interaction between dietary fat intake and metabolic genetic risk score on 25-hydroxyvitamin D concentrations in a Turkish adult population. Nutrients 2022, 14, 382. [CrossRef]

28. Gibson, R.S. Principles of Nutritional Assessment; Oxford University Press: New York, NY, USA, 2005.

29. Lohman, T.; Roche, A.F.; Martorell, R. (Eds.) Anthropometric Standardization Reference Manual; Human Kinetics Books: Champaign, IL, USA, 1988.

30. De Lorenzo, A.; Martinoli, R.; Vaia, F.; Di Renzo, L. Normal weight obese (NWO) women: An evaluation of a candidate new syndrome. Nutr. Metab. Cardiovasc. Dis. 2006, 16, 513-523. [CrossRef]

31. Kim, M.K.; Han, K.; Kwon, H.S.; Song, K.H.; Yim, H.W.; Lee, W.C.; Park, Y.M. Normal weight obesity in Korean adults. Clin. Endocrinol. 2014, 80, 214-220. [CrossRef]

32. Oliveros, E.; Somers, V.K.; Sochor, O.; Goel, K.; Lopez-Jimenez, F. The concept of normal weight obesity. Prog. Cardiovasc. Dis. 2014, 56, 426-433. [CrossRef]

33. Wagner, D.; Hanwell, H.E.; Vieth, R. An evaluation of automated methods for measurement of serum 25-hydroxyvitamin D. Clin. Biochem. 2009, 42, 1549-1556. [CrossRef]

34. Climate-Data.org. Goiás Climate. 2021. Available online: https://en.climate-data.org/south-america/brazil/goias/goias-879942 / (accessed on 12 August 2021).

35. Spark, W. Average Weather in Goiás. 2021. Available online: https://weatherspark.com/y/29864/Average-Weather-in-Goi\%C3 $\% A 1$ s-Brazil-Year-Round (accessed on 12 August 2021).

36. Køster, B.; Søndergaard, J.; Nielsen, J.B.; Allen, M.; Olsen, A.; Bentzen, J. The validated sun exposure questionnaire: Association of objective and subjective measures of sun exposure in a Danish population-based sample. Br. J. Dermatol. 2017, 176, 446-456. [CrossRef] [PubMed]

37. Yang, Y.J.; Kim, M.K.; Hwang, S.H.; Ahn, Y.; Shim, J.E.; Kim, D.H. Relative validities of 3-day food records and the food frequency questionnaire. Nutr. Res. Pract. 2010, 4, 142-148. [CrossRef] [PubMed]

38. Nakhl, S.; Sleilaty, G.; Chouery, E.; Salem, N.; Chahine, R.; Farès, N. FokI vitamin D receptor gene polymorphism and serum 25-hydroxyvitamin D in patients with cardiovascular risk. Arch. Med. Sci. Atheroscler Dis. 2019, 4, e298-e303. [CrossRef] [PubMed]

39. Tuncel, G.; Temel, S.G.; Ergoren, M.C. Strong association between VDR FokI (rs2228570) gene variant and serum vitamin D levels in Turkish cypriots. Mol. Biol. Rep. 2019, 46, 3349-3355. [CrossRef] [PubMed]

40. Foucan, L.; Velayoudom-Cephise, F.L.; Larifla, L.; Armand, C.; Deloumeaux, J.; Fagour, C.; Plumasseau, J.; Portlis, M.L.; Liu, L.; Bonnet, F.; et al. Polymorphisms in GC and NADSYN1 Genes are associated with vitamin D status and metabolic profile in Non-diabetic adults. BMC Endocr. Disord. 2013, 13, 36-43. [CrossRef]

41. Wang, T.J.; Zhang, F.; Richards, J.B.; Kestenbaum, B.; van Meurs, J.B.; Berry, D.; Kiel, D.P.; Streeten, E.A.; Ohlsson, C.; Koller, D.L.; et al. Common genetic determinants of vitamin D insufficiency: A genome-wide association study. Lancet. 2010, 376, 180-188. [CrossRef]

42. Xu, X.; Mao, J.; Zhang, M.; Liu, H.; Li, H.; Lei, H.; Han, L.; Gao, M. Vitamin D Deficiency in Uygurs and Kazaks is associated with polymorphisms in CYP2R1 and DHCR7/NADSYN1 Genes. Med. Sci. Monit. Int. Med. J. Exp. Clin. Res. 2015, $21,1960-1968$.

43. Zhang, Y.; Wang, X.; Liu, Y.; Qu, H.; Qu, S.; Wang, W.; Ren, L. The GC, CYP2R1 and DHCR7 genes are associated with vitamin D levels in northeastern Han Chinese children. Swiss. Med. Wkly. 2012, 142, w13636. [CrossRef]

44. Elkum, N.; Alkayal, F.; Noronha, F.; Ali, M.M.; Melhem, M.; Al-Arouj, M.; Bennakhi, A.; Behbehani, K.; Alsmadi, O.; Abubaker, J Vitamin D insufficiency in Arabs and South Asians positively associates with polymorphisms in GC and CYP2R1 genes. PLoS ONE 2014, 9, e113102. [CrossRef]

45. Kwak, S.Y.; Yongjoo Park, C.; Jo, G.; Yoen Kim, O.; Shin, M.J. Association among genetic variants in the vitamin D pathway and circulating 25-hydroxyvitamin D levels in Korean adults: Results from the Korea National Health and Nutrition Examination Survey 2011-2012. Endocr. J. 2018, 65, 881-891. [CrossRef]

46. Bego, T.; Čaušević, A.; Dujić, T.; Malenica, M.; Velija-Asimi, Z.; Prnjavorac, B.; Marc, J.; Nekvindová, J.; Palička, V.; Semiz, S. Association of FTO gene variant (rs8050136) with type 2 diabetes and markers of obesity, glycaemic control and inflammation. $J$. Med. Biochem. 2019, 38, 153-163. [CrossRef] [PubMed]

47. Chris, A.; Narila, N.; Flori, S.; Risfy, P.; Intan, A.; Zeti, H.; Witri, A.; Hari, H.; Nouval, S.; Endah, W.; et al. Preliminary study: Identification of DNA variation with SNP numbers RS1137101 and RS8050136 in patient's type 2 diabetes mellitus at salsabila clinic bogor-Indonesia. Asian J. Microbiol. Biotechnol. Environ. Sci. 2019, 21, 931-934.

48. Li, H.; Kilpelainen, T.O.; Liu, C.; Zhu, J.; Liu, Y.; Hu, C.; Yang, Z.; Zhang, W.; Bao, W.; Cha, S.; et al. Association of genetic variation in FTO with risk of obesity and type 2 diabetes with data from 96,551 East and South Asians. Diabetologia 2012, 55, 981-995. [CrossRef] [PubMed]

49. Vasan, S.K.; Karpe, F.; Gu, H.F.; Brismar, K.; Fall, C.H.; Ingelsson, E.; Fall, T. FTO genetic variants and risk of obesity and type 2 diabetes: A meta-analysis of 28,394 Indians. Obesity 2014, 22, 964-970. [CrossRef] [PubMed] 
50. Vimaleswaran, K.S.; Angquist, L.; Hansen, R.D.; Daphne, L.v.d.A.; Bouatia-Naji, N.; Holst, C.; Tjonneland, A.; Overvad, K.; Jakobsen, M.U.; Boeing, H.; et al. Association between FTO variant and change in body weight and its interaction with dietary factors: The DiOGenes study. Obesity 2012, 20, 1669-1674. [CrossRef] [PubMed]

51. Vimaleswaran, K.S.; Bodhini, D.; Lakshmipriya, N.; Ramya, K.; Anjana, R.M.; Sudha, V.; Lovegrove, J.A.; Kinra, S.; Mohan, V.; Radha, V. Interaction between FTO gene variants and lifestyle factors on metabolic traits in an Asian Indian population. Nutr. Metab. 2016, 13, 39. [CrossRef] [PubMed]

52. Bodhini, D.; Gaal, S.; Shatwan, I.; Ramya, K.; Ellahi, B.; Surendran, S.; Sudha, V.; Anjana, M.R.; Mohan, V.; Lovegrove, J.A.; et al. Interaction between TCF7L2 polymorphism and dietary fat intake on high density lipoprotein cholesterol. PLoS ONE 2017, 12, e0188382. [CrossRef]

53. Chauhan, G.; Spurgeon, C.J.; Tabassum, R.; Bhaskar, S.; Kulkarni, S.R.; Mahajan, A.; Chavali, S.; Kumar, M.V.K.; Prakash, S.; Dwivedi, O.P.; et al. Impact of common variants of PPARG, KCNJ11, TCF7L2, SLC30A8, HHEX, CDKN2A, IGF2BP2, and CDKAL1 on the risk of type 2 diabetes in 5164 Indians. Diabetes 2010, 59, 2068-2074. [CrossRef]

54. Chidambaram, M.; Liju, S.; Saboo, B.; Sathyavani, K.; Viswanathan, V.; Pankratz, N.; Gross, M.; Mohan, V.; Radha, V. Replication of genom-Wide association signals in Asian Indians with early-onset type 2 diabetes. Acta Diabetol 2016, 53, 915-923. [CrossRef]

55. Gupta, V.; Khadgawat, R.; Ng, H.K.T.; Walia, G.K.; Kalla, L.; Rao, V.R.; Sachdeva, M.P. Association of TCF7L2 and ADIPOQ with body mass index, waist-hip ratio, and systolic blood pressure in an endogamous ethnic group of India. Genet. Test. Mol. Biomark. 2012, 16, 948-951. [CrossRef]

56. Khan, I.A.; Poornima, S.; Jahan, P.; Rao, P.; Hasan, Q. Type 2 Diabetes mellitus and the association of candidate genes in Asian Indian population from Hyderabad, India. J. Clin. Diagn. Res. 2015, 9, Gc01-Gc05. [CrossRef] [PubMed]

57. Phani, N.M.; Adhikari, P.; Nagri, S.K.; D'Souza, S.C.; Satyamoorthy, K.; Rai, P.S. Replication and Relevance of multiple susceptibility loci discovered from genome wide association studies for type 2 diabetes in an indian population. PLOS ONE 2016, 11, e0157364. [CrossRef] [PubMed]

58. Srivastava, A.; Mittal, B.; Prakash, J.; Srivastava, P.; Srivastava, N.; Srivastava, N. A multianalytical approach to evaluate the association of 55 SNPs in 28 genes with obesity risk in North Indian adults. Am. J. Hum. Biol. 2017, 29, e22923. [CrossRef] [PubMed]

59. Apalasamy, Y.D.; Ming, M.F.; Rampal, S.; Bulgiba, A.; Mohamed, Z. Association of melanocortin-4 receptor gene polymorphisms with obesity-related parameters in Malaysian Malays. Ann. Hum. Biol. 2013, 40, 102-106. [CrossRef]

60. Srivastava, A.; Mittal, B.; Prakash, J.; Narain, V.S.; Natu, S.M.; Srivastava, N. Evaluation of MC4R [rs17782313, rs17700633], AGRP [rs3412352] and POMC [rs1042571] polymorphisms with obesity in Northern India. Oman. Med. J. 2014, 29, 114-118. [CrossRef]

61. Srivastava, A.; Mittal, B.; Prakash, J.; Srivastava, P.; Srivastava, N. Analysis of MC4R rs17782313, POMC rs1042571, APOE-Hha1 and AGRP rs3412352 genetic variants with susceptibility to obesity risk in North Indians. Ann. Hum. Biol. 2016, 43, 285-288. [CrossRef]

62. Vasan, S.K.; Fall, T.; Neville, M.J.; Antonisamy, B.; Fall, C.H.; Geethanjali, F.S.; Gu, H.F.; Raghupathy, P.; Samuel, P.; Thomas, N.; et al. Associations of variants in FTO and near MC4R with obesity traits in South Asian Indians. Obesity 2012, 20, $2268-2277$. [CrossRef]

63. Been, L.F.; Ralhan, S.; Wander, G.S.; Mehra, N.K.; Singh, J.; Mulvihill, J.J.; Aston, C.E.; Sanghera, D.K. Variants in KCNQ1 increase type II diabetes susceptibility in South Asians: A study of 3310 subjects from India and the US. BMC Med. Genet. 2011, 12, 18. [CrossRef]

64. Qi, Q.; Li, H.; Loos, R.J.F.; Liu, C.; Wu, Y.; Hu, F.B.; Wu, H.; Lu, L.; Yu, Z.; Lin, X. Common variants in KCNQ1 are associated with type 2 diabetes and impaired fasting glucose in a Chinese Han population. Hum. Mol. Genet. 2009, 18, 3508-3515. [CrossRef]

65. Binh, T.Q.; Thu, N.T.T.; Phuong, P.T.; Nhung, B.T.; Nhung, T.T.H. CDKN2A-rs10811661 polymorphism, waist-hip ratio, systolic blood pressure, and dyslipidemia are the independent risk factors for prediabetes in a Vietnamese population. BMC Genet. 2015, 16, 1-8. [CrossRef]

66. Plengvidhya, N.; Chanprasert, C.; Chongjaroen, N.; Yenchitsomanus, P.-t.; Homsanit, M.; Tangjittipokin, W. Impact of KCNQ1, CDKN2A/2B, CDKAL1, HHEX, MTNR1B, SLC30A8, TCF7L2, and UBE2E2 on risk of developing type 2 diabetes in Thai population. BMC Med. Genet. 2018, 19, 93. [CrossRef] [PubMed]

67. Zhao, Q.; Xiao, J.; He, J.; Zhang, X.; Hong, J.; Kong, X.; Mills, K.T.; Weng, J.; Jia, W.; Yang, W. Cross-sectional and longitudinal replication analyses of genome-wide association loci of type 2 diabetes in Han Chinese. PLoS ONE 2014, 9, e91790. [CrossRef]

68. Ho, J.S.K.; Germer, S.; Tam, C.H.T.; So, W.-Y.; Martin, M.; Ma, R.C.W.; Chan, J.C.N.; Ng, M.C.Y. Association of the PPARG Pro12Ala polymorphism with type 2 diabetes and incident coronary heart disease in a Hong Kong Chinese population. Diabetes Res. Clin. Pract. 2012, 97, 483-491. [CrossRef] [PubMed]

69. Prakash, J.; Srivastava, N.; Awasthi, S.; Agarwal, C.; Natu, S.; Rajpal, N.; Mittal, B. Association of PPAR- $\gamma$ gene polymorphisms with obesity and obesity-associated phenotypes in North Indian population. Am. J. Hum. Biol. 2012, 24, 454-459. [CrossRef] [PubMed]

70. Sanghera, D.K.; Ortega, L.; Han, S.; Singh, J.; Ralhan, S.K.; Wander, G.S.; Mehra, N.K.; Mulvihill, J.J.; Ferrell, R.E.; Nath, S.K.; et al. Impact of nine common type 2 diabetes risk polymorphisms in Asian Indian Sikhs: PPARG2 (Pro12Ala), IGF2BP2, TCF7L2 and FTOvariants confer a significant risk. BMC Med. Genet. 2008, 9, 59. [CrossRef]

71. Cui, J.; Xu, X.; Yin, S.; Chen, F.; Li, P.; Song, C. Meta-analysis of the association between four CAPN10 gene variants and gestational diabetes mellitus. Arch. Gynecol. Obstet. 2016, 294, 447-453. [CrossRef] 
72. Bodhini, D.; Radha, V.; Ghosh, S.; Sanapala, K.R.; Majumder, P.P.; Satyanarayana Rao, M.R.; Mohan, V. Association of calpain 10 gene polymorphisms with type 2 diabetes mellitus in Southern Indians. Metabolism 2011, 60, 681-688. [CrossRef]

73. Moreira, C.A.; Ferreira, C.; Madeira, M.; Silva, B.C.C.; Maeda, S.S.; Batista, M.C.; Bandeira, F.; Borba, V.Z.C.; Lazaretti-Castro, M. Reference values of 25-hydroxyvitamin D revisited: A position statement from the Brazilian Society of Endocrinology and Metabolism (SBEM) and the Brazilian society of clinical pathology/laboratory medicine (SBPC). Arch. Endocrinol. Metab. 2020, 64, 462-478. [CrossRef]

74. De Souza, R.J.; Bray, G.A.; Carey, V.J.; Hall, K.D.; LeBoff, M.S.; Loria, C.M.; Laranjo, N.M.; Sacks, F.M.; Smith, S.R. Effects of 4 weight-loss diets differing in fat, protein, and carbohydrate on fat mass, lean mass, visceral adipose tissue, and hepatic fat: Results from the POUNDS LOST trial. Am. J. Clin. Nutr. 2012, 95, 614-625. [CrossRef]

75. Zhou, T.; Sun, D.; Heianza, Y.; Li, X.; Champagne, C.M.; LeBoff, M.S.; Shang, X.; Pei, X.; Bray, G.A.; Sacks, F.M.; et al. Genetically determined vitamin $\mathrm{D}$ levels and change in bone density during a weight-loss diet intervention: The preventing overweight using novel dietary strategies (pounds lost) trial. Am. J. Clin. Nutr. 2018, 108, 1129-1134. [CrossRef]

76. Bonjour, J.-P.; Kraenzlin, M.; Levasseur, R.; Warren, M.; Whiting, S. Dairy in adulthood: From foods to nutrient interactions on bone and skeletal muscle health. J. Am. Coll. Nutr. 2013, 32, 251-263. [CrossRef] [PubMed]

77. Cashman, K.D.; van den Heuvel, E.G.; Schoemaker, R.J.; Prévéraud, D.P.; Macdonald, H.M.; Arcot, J. 25-Hydroxyvitamin D as a biomarker of vitamin D status and its modeling to inform strategies for prevention of vitamin D deficiency within the population. Adv. Nutr. 2017, 8, 947-957. [CrossRef] [PubMed]

78. Baig, J.A.; Sheikh, S.A.; Islam, I.; Kumar, M. Vitamin D status among vegetarians and non-vegetarians. J. Ayub. Med. Coll. Abbottabad. 2013, 25, 152-155. [PubMed]

79. Souza, R.A.; Yokoo, E.M.; Sichieri, R.; Pereira, R.A. Energy and macronutrient intakes in Brazil: Results of the first nationwide individual dietary survey. Public Health Nutr. 2015, 18, 3086-3095. [CrossRef] [PubMed]

80. World Cancer Research Fund/American Institute for Cancer Research. Food, Nutrition, Physical Activity, and the Prevention of Cancer: A Global Perspective; AICR: Washington, DC, USA, 2007.

81. World Health Organization. Diet, nutrition and the prevention of chronic diseases: Report of a joint WHO/FAO expert consultation, Geneva, 28 January-1 February 2002. 2003. World Health Organization. Available online: https://apps.who.int/ iris/handle/10665/42665 (accessed on 9 December 2021).

82. World Health Organization. Prevention of cardiovascular disease:Pocket guidelines for assessment and management of cardiovascular risk:(WHO/ISH cardiovascular risk prediction charts for the European Region). World Health Organization. 2007. Available online: https:/ /apps.who.int/iris/andle/10665/43784 (accessed on 9 December 2021).

83. Berry, D.J.; Vimaleswaran, K.S.; Whittaker, J.C.; Hingorani, A.D.; Hypponen, E. Evaluation of genetic markers as instruments for Mendelian randomization studies on vitamin D. PLoS ONE 2012, 7, e37465. [CrossRef]

84. Dudbridge, F. Polygenic epidemiology. Genet. Epidemiol. 2016, 40, 268-272. [CrossRef]

85. Liu, W.; Icitovic, N.; Shaffer, M.L.; Chase, G.A. The impact of population heterogeneity on risk estimation in genetic counseling. BMC Med. Genet. 2004, 5, 18. [CrossRef]

86. Hellwege, J.N.; Keaton, J.M.; Giri, A.; Gao, X.; Velez Edwards, D.R.; Edwards, T.L. Population Stratification in genetic association studies. Curr. Protoc. Hum. Genet. 2017, 95, 1.22.1-1.22.23. [CrossRef]

87. Kehdy, F.S.; Gouveia, M.H.; Machado, M.; Magalhães, W.C.; Horimoto, A.R.; Horta, B.L.; Moreira, R.G.; Leal, T.P.; Scliar, M.O.; Soares-Souza, G.B.; et al. Origin and dynamics of admixture in Brazilians and its effect on the pattern of deleterious mutations. Proc. Natl. Acad. Sci. USA 2015, 112, 8696-8701. [CrossRef]

88. Souza, A.M.; Resende, S.S.; Sousa, T.N.; Brito, C.F.A. A systematic scoping review of the genetic ancestry of the Brazilian population. Genet. Mol. Biol. 2019, 42, 495-508. [CrossRef]

89. National Center for Biotechnology Information. Available online: https://www.ncbi.nlm.nih.gov/snp/ (accessed on 12 August 2021). 